\title{
The Power Of CSR Strategy To Enhance Marketing Performance (An Empirical Study on Print-Off Events by Jawa Pos Daily Newspaper)
}

\author{
Arif Jauhar Tontowi, Djumilah Hadiwidjojo, Surachman, and Siti Aisjah \\ Faculty of Economics and Business, Brawijaya University, Malang, Indonesia
}

\begin{abstract}
A distint phenomenon has been found from Jawa Pos daily newspaper as the one with the highest amount of oplaag and readers (over 1.4 millions) in Indonesia. The company has implemented a CSR (Corporate Social Responsibility) stratety partaking its marketing strategies. The actual implementation of the strategy, known as "Print-Off Events" which, as the name suggests, means non-printing activities, consists of being the initiator of the following events: Development Basket Ball League (DBL) Indonesia, Untukmu Guruku, Smart Riding, Surabaya Green and Clean, NBA Madness by Jawa Pos, and many more.

This study aimed at testing and describing how the CSR strategy influenced its marketing performance directly and indirectly through two mediating variables, namely, value creation and relational reward. Employing Structural Equation Modelling (SEM) as a primary means of analysis, data were obtained from 115 respondents from different levels as the internal marketing unit (marketing and event managers) and the external one (agents). The analysis shows that the strategy does not directly have any significant influence towards the marketing performance, yet it indirectly has a significant influence. This study has succeeded in prooving that two mediating variables, namely, value creation and relational reward, contribute to the increase in the marketing performance after the newspaper company implements its CSR strategy.

Theoretically, this study may draw future researchers' attention on the same topic to explore deeper and wider the effect of the CSR implementation towards the company performance. Practically, the result of the study would foster the implementation of CSR among the industrial world as social and business missions can be synergically saturated when the CSR strategy is integrated into the whole company's strategies.
\end{abstract}

Keywords: CSR Strategy, Value Creation, Relational Reward, Marketing Performance.

\section{Introduction}

Controversies in the result of many studies around the positive or negative effect of the practices of CSR (Corporate Social Responsibility) towards the company's performance remain arising. This circumstance gives chances for scholars to conduct more research, deeper, so that new findings and conclusions can be made againts the controversies. Whenever the latter condition takes place, there would be many more-effectively designs of CSR programs for the sake of hindering companies from their negative effects, leading them to the positive effects which are to boost the company's performance.

Many scholars support the argument that the implementation of CSR can bring to positive ramifications to a company; one of them is Porter (1995, in Husted \& Allen, 2007) who asserts that CSR can be a source of benefit and inovation, and competitive advantage and value creation, implying that the implementation of CSR must have positive impact on the performance as a whole. If any significant result has not been achieved by a company with CSR strategy, there must be something wrong in the implementation. Therefore, the researchers believe that more research needs to be conducted, particularly the one that can lead to strong evidence that the integration of CSR into the management, with specially-educated people in the field of CSR assigned to take action, will result in positive impact on the company's performance. Once this achieved, CSR will gain supports from businessmen and encourage companies to integrate it into the management process.

Husted and Allen (2007), at the end of their research report, suggest to future research that CSR be integrated into the processes within the company in order to bring into it high competitive advantage and outstanding economic performance. Their suggestion inspired the researchers to study how strong (effective) CRS was when it was integrated into marketing strategy which served as the core discussion of the rest of this article. In their study, Husted and Allen made use three dimensions of the strategic variable of CSR, that is, visibility, appropriability, and voluntarism, within the process of value creation of large companies in Spain. The value creation variable is the one to be tested in the current study. The variable indicators of CSR strategy adopt their study.

Du, Bhattacharya, and Sen (2007), in their research, conclude that the positive impact on the side of the customers with regard to the company's CSR deals not only with more sales but also with long-term loyalty to the company and their buying attitudes. That is to say, the argument that CSR-related activities will bring great 
impact to the performance receives stronger support. Other finding that contributes to the basis of the present study is the statement that says that a brand which integrates its main business strategies with certain CSR strategy tends to gain more profit than others which separate the CSR from their main strategies. Furthermore, another important variable, relational reward, serves as the one that is re-tested within the study as a mediating variable.

Falck and Heblich (2007) assert that practicing CSR strategically, a company could "do good by doing good". That is to say, a CSR-based company would gain better profit and, at the same time, make the world a better place for living. By the end of this article, we are not to say that companies focus merely on CSR, forgetting their main missions; instead, the practice of CSR is seen as a means for establishing well-prospered both the companies and society.

Henderson (2007) found that there remains confusion among managers in distinguishing between commercial-based activities and the charity-based ones, leading to more empirical evicence to encourage them in applying and developing CSR practices within their respective companies. Another thing that can be inferred from Henderson's report is the fact that studies in CSR have not been equally spread in the international map; up to now academical references and news reports on CSR remains circling around Western context, and cases were discussed within the context of European and North American countries. The idea of CSR is relatively new to most Asian countries, particularly those in South East Asia. This fact has contributed to the choice of location in which the present study was conducted. We believe that it has been the time for empirical studies to discuss the implementation of CSR by large companies in the area which have huge committments to the idea of CSR for the sake of analysing how far CSR has been conducted by those companies. Therefore, this study focused on the practices of CSR in Indonesia, the largest country in South East Asia, particularly in one of its large newspaper companies called Jawa Pos.

In an early observation on the management of Jawa Pos, we found a unique phenomenon as to how the company conduct its CSR practices. The company took itself as the main sponsor to the so-called Print-Off Events, coined name for the implementation of CSR in Jawa Pos, which, as the name suggests, means activities outside printing activities, such as Development Basketball League (DBL) Indonesia, Untukmu Guruku (a program dedicated for school teachers), Smart Riding, Surabaya Green and Clean, NBA Madness by Jawa Pos, and so on. The company made these events as one of their marketing strategies to boost its performance. Based on a survey conducted by MarkPlus (2010), news about the CSR projects, particularly those reporting on DBL Indonesia, published in the newspaper has been able to drive up teenagers' willing to read newspaper in Surabaya up to $94 \%$. It is the existence of these Print-Off Events in a consistent manner that could keep and rise the number of its readers within the last decade, deserving to be awarded "Greatest Brand of the Decade". Moreover, in 2011 Jawa Pos received some worldwide achievements, "World Young Reader Newspaper of the Year", "Indonesia's Most Favourite Woman Brand", and "Indonesia's Most Favourite Youth Brand", to name a few.

Looking at the compilation of theories concerning CSR, and a unique phenomenon on the implementation of CSR in the form of Print-Off Events as a marketing strategy by Jawa Pos daily newspaper, a question arises, whether the fact is a kind of link and match, being categorized as a projection of concepts into a real phenomenon. It is from this reason that the Print-Off Events were found to be worth analysing, encouraging the researchers to test its truth.

\section{Objectives}

1. To find out the impact of CSR strategy on value creation

2. To find out the impact of CSR strategy on relational reward

3. To find out the impact of CSR strategy on the marketing performance

4. To find out the impact of value creation on the marketing performance

5. To find out the impact of relational reward on the marketing performance

\section{1. Corporate Social Resposibility (CSR)}

\section{Literature Review}

The foundation of the concept of CSR lies upon the encouragement that the business world has to take a bigger role in the society (i.e. the non-economic role) than merely producing goods and services and gaining profit for itself. This role demands businessmen to get involved in social and environmental activities, meaning that they are to think further than merely profit-oriented activities, involve themselves in establishing good society and nice environment, making the world a better place to live (Robins, 2005, in Malovics, Csigene, \& Kraus, 2007).

Generosity and social initiative (in other words, corporate social responsibility) should be the core and soul of any business activities (Levi, 1999). Levi (1999) also states that the social activities have to be in accordance with the objectives of a company and should be the place to express its value (soul). Therefore, the 
implementation of CSR needs a well-integrated strategy within the process of the company so that it supports the expected performance. Empirically, Olsen, Cudmore, and Hill (2005), American researchers, believe that when social initiatives are not in line with the missions of a company (mismatching), CSR may turn out to be a disadvantage for the company and lessen people's trust. Therefore, management of companies needs to selectively assign social programs to be conducted and ensures mutual communication between the companies and the society so that they are seen as proactive and their customers get motivated socially.

Findings derived from two researches conducted by Olsen, Cudmore, and Hill (2007) in the United States are considered interesting as the first research found that as many as $80 \%$ of the respondents believe that companies should partake in a considerable social initiatives, and $76 \%$ believe that such initiatives would benefit the companies. And, the second research found that $52 \%$ of the respondents state that they will boycott products from companies which ignore their corporate responsibility.

$\mathrm{Du}$, Bhattacharya, and Sen (2007) point out that, unlike other other primary strategies, practices of CSR can make a company or a brand seem more human which drive people to not only love, respect, and adore but also identify the company or brand. Logically speaking, this act of identification by its customers will plant its brand inside their mind in a long term and, moreover, build loyalty to the products, making the customers as natural guards for the products. In details, at least there are 5 (five) kinds of advantages that a company can derive from its sustained CSR strategy according to Lako (2008); they are (1) stronger profitability and financial performance, (2) higher accountability and positive appreciation from investors, creditors, supplyers, and customers, (3) higher employees' committment, work ethics, efficiency, and productivity, (4) lower potential of social disturbance and resistence from its surrounding, and (5) better reputation, corporate branding, goodwill (intangible asset), and the company's value in a long term. The latter is of primarily importance in establishing a continuous dynamic strenght of the company. Therefore, CSR program must be ethically and continuously practiced and internalized within the values of corporate culture and the company's strategies (Indarti, 2010).

\subsection{Marketing Strategy}

Philip Kotler (2003) defines strategy as a set of game plans to achieve a certain objective. The strategy may consist of marketing strategy, technological strategy, or a strategy aimed at finding an appropriate source. The initial concept of strategy begins from the concept of how to optimalize the company's source in the most effective manner within a changing environment. Environment means various factors outside the company which can be seen as either opportunities or threats. When the environment provides many opportunities, the company's strategy needs to be re-designed for the sake achieving more; but when it provides threats, the strategy also needs to be reformed to avoid bigger gaps with the company's achievement.

Another thing that leaders of the management need to pay attention to, beside external environment, is the internal environment. This need to be well identified to lessen, or diminish, the company's weaknesses and build its strengths to reach a considerable extent of competitive advantage. Knowing these, analyses of strategies to determine the most effective way in taking benefits from identified opportunities and in dealing with potential threats can be made.

In general, Michel Porter (1993, in Douglas, 1995) offers three generic competitive strategies consisting of the followings.

1. Cost Leadership Strategy, this infers that companies need to aggresively facilitate efficiency in operation and tightly manage its cost and overheads, so that they are able to set prices below their competitors.

2. Differentiation Strategy, in which companies attempt to create products valuably different from competitors.

3. Focus Strategy, in which companies put their full attention to a particular segmented market in addition to implementing the differentiation strategy and the cost leadership strategy. Moreover, Porter asserts that this strategy is based around the belief that companies will serve better their narrow but segmented market more effectively and efficiently than their competitors which have to deal with larger market.

\subsection{Marketing Performance}

An evaluation to a company's performance is of great importance, not only for the sake of measuring how far the company has been going at a certain time or period but also being a foundation for feedbacks for the betterment of its performance in the future. Nevertheless, a challenge for researchers lies upon defining or assessing performance as it is something complex that needs careful consideration in doing so. The solution for this is to see marketing performance as one important element of the company's performance as a whole. It represents a concept on how the marketing achievement of the company is measured and put it as a means of determining the success of the company in the market competition. In general, marketing performance serves as a construct which is measured as an impact of the implementation of the company's strategies. And this study would use the same idea of using marketing performance as the basis of determining the success of the implementation of CSR strategy. Despite its common use to measure the result of the implementation of 
strategies, the way to measure marketing performance remains an issue as it is multi-dimensional with regard to various objectives and types of organization. Therefore, multiple measurement involving many criteria at once is better than single measurement as the latter can doubtly give a better picture of the real performance.

Keats et al. (1998) argue that marketing performance may refer to the ability of the organization to transform itself in one way or another so that it is able to deal with challenges from external environment within a long term. That is to say, an evaluation on it serves as an attempt to see whether the implemented strategies are able to face those challenges. The ability of the company to learn about changes and demands from its surrounding will create new opportunities and, thus, demand adaptation and development in terms of its strategies, so that achievement-gaining is sustained.

Marketing performance is commonly measured through return on investment (RoI) and return on assets (RoA); however, these are merely seen as aggregative measures as a result of some accounting and financial process, unable to directly picture the activities of the management, particularly the marketing management (Ferdinand, 2000). Therefore, it is suggested that activity-based measurement be used in this case to explain marketing activities that result in marketing performance.

Menon et al. (1996) offers that marketing performance can be measured through the level of market share, net profit, and sales growth rate. This is in line with what Kotabe et al. (1991) point out that variables of marketing performance comprise:

1. Market share relative, measured by comparing the volume of the company's sales and of the closest competitor's sales.

2. Sales growth rate, measured in the form of percentages.

3. Profit before taxes, measured by comparing net profit before taxes and the amount of investment.

\section{Methodology}

The present study employed quantitative approach. Data were collected from survey methods, namely, interview and questionnaire. The research instrument was a set of questions (in questionnaire) distributed to the respondents consisting of the management of Jawa Pos daily newspaper (3 units) and the agents (112 units), all located in the Head Office in Surabaya which is the city where most of the Print-Off Events were held.

The kind of analysis employed in the study was the inferential statistical analysis. The analysis of data from the respondents used the Structural Equation Modelling (SEM) with the assist of AMOS 6 and SPSS 16 programs.

Formulating the structural equation model in the study referred to the steps once developed by hair (2006) which comprise: (1) Theoretical-based Model Development, (2) Path Diagram Development, (3) Evaluation on Goodness of Fit Criteria, (4) Assumption Assessment of the SEM, and (5) Structural Model Testing: Testing the Research Hypothesis.

\subsection{Research Instrument Testing}

\section{Findings And Discussion}

Table 1 shows the result of the research instrument testing (in terms of validity and reliability).

Table 1. Validity and Reliability Testing

\begin{tabular}{|c|c|c|c|c|c|c|c|c|}
\hline \multicolumn{3}{|c|}{$\begin{array}{c}\text { CSR Strategy } \\
\text { (X) }\end{array}$} & \multicolumn{2}{|c|}{$\begin{array}{c}\text { Value Creation } \\
\text { (Y1) }\end{array}$} & \multicolumn{2}{|c|}{$\begin{array}{c}\text { Relational Reward } \\
\text { (Y2) }\end{array}$} & \multicolumn{2}{|c|}{$\begin{array}{c}\text { Marketing } \\
\text { Performance (Y3) }\end{array}$} \\
\hline Dimension & Indicator & Correlation & Indicator & Correlation & Indicator & Correlation & Indicator & Correlation \\
\hline \multirow[t]{2}{*}{$\mathrm{X} 1$} & $\mathrm{X} 11$ & 0.563 & Y11 & 0.742 & $\mathrm{Y} 21$ & 0.800 & Y31 & 0.758 \\
\hline & $\mathrm{X} 12$ & 0.679 & $\mathrm{Y} 12$ & 0.776 & $\mathrm{Y} 22$ & 0.790 & Y32 & 0.835 \\
\hline $\mathrm{X} 2$ & $\mathrm{X} 21$ & 0.686 & Y13 & 0.727 & Y23 & 0.787 & Y33 & 0.791 \\
\hline \multirow[t]{2}{*}{$\mathrm{X} 3$} & $\mathrm{X} 31$ & 0.755 & $\mathrm{Y} 14$ & 0.662 & & & & \\
\hline & X32 & 0.676 & & & & & & \\
\hline \multicolumn{3}{|c|}{ Alpha Cronbach $=0.751$} & \multicolumn{2}{|c|}{ Alpha Cronbach $=0.703$} & \multicolumn{2}{|c|}{ Alpha Cronbach $=0.703$} & \multicolumn{2}{|c|}{ Alpha Cronbach $=0.705$} \\
\hline
\end{tabular}

Source: Data analysis, 2012

\subsection{The SEM Analysis}

\subsubsection{Normality}

The assumption of multivariate normality was tested with the help of AMOS 6 computer software. The result was that the value of critical ratio was -0.943 with critical value $Z_{\text {counted }}$ for $\alpha 5 \%$ was 1.96 . Since the $C R$ absolute value of multivariate showed that $0.943<1.96$, the assumption of multivariate normality was satisfied. 


\subsubsection{Outlier}

When the Md of the observation spot $>107.2579$, then that was said as outlier. On the contrary, when the Md of the observation spot $<107.2579$, then that cannot be said as outlier. The table of Mahalanobis distance shows that the farthes observation spot was the $53^{\text {rd }}$ respondent with Md value $=27.410$. If this was to be compared with the value of $\chi_{66}^{2}=107.2579$, then the value of Md in the $53^{\text {rd }}$ spot $<107.2579$, and, thus, all the observation spots were not outlier.

\subsubsection{Linearity}

Table 2. Result of Testing on Linearity Assumption

\begin{tabular}{|c|c|c|c|}
\hline \multicolumn{2}{|c|}{ Relationship between Variables } & Result & Signification \\
\hline CSR Strategy (X) & Value Creation (Y1) & Sig for all models $<0.05$ & Linier \\
\hline CSR Strategy (X) & Relational Reward (Y2) & Sig for all models $<0.05$ & Linier \\
\hline CSR Strategy (X) & Marketing Performance (Y3) & Sig for all models $<0.05$ & Linier \\
\hline Value Creation (Y1) & Marketing Performance (Y3) & Sig for all models $<0.05$ & Linier \\
\hline Relational Reward (Y2) & Marketing Performance (Y3) & Sig for all models $<0.05$ & Linier \\
\hline
\end{tabular}

Source: Data analysis, 2012

\subsection{Goodness Of Fit Overall Model}

Table 3. Result of Testing on Goodness Of Fit Overall Model

\begin{tabular}{|l|c|c|c|}
\hline \multicolumn{1}{|c|}{ Criteria } & Cut-of Value & Result & Signification \\
\hline Khi Quadratic & Small & 77.779 & \multirow{2}{*}{ Good } \\
\hline p-value & $\geq 0.05$ & 0.641 & Good \\
\hline CMIN/DF & $\leq 2.00$ & 0.937 & Good \\
\hline GFI & $\geq 0.90$ & 0.920 & Poor \\
\hline AGFI & $\geq 0.90$ & 0.884 & Good \\
\hline TLI & $\geq 0.95$ & 1.019 & Good \\
\hline CFI & $\geq 0.95$ & 1.000 & Good \\
\hline RMSEA & $\leq 0.08$ & 0.000 & \\
\hline
\end{tabular}

Source: Data analysis, 2012

\subsection{Measurement Model (CFA)}

Table 4. Result of Testing on Measurement Model

\section{CSR Strategy Variable (X)}

Dimension/Indicator

X.1 = Visibility

$\mathrm{X} 1.1$ = The company's image improvement

$\mathrm{X} 1.2=\mathrm{CSR}$ activities published in media

$\mathrm{X} .2=$ Appropriability

$\mathrm{X} 2.1$ = Financial revenue achievement level

X.3 = Voluntarism

$\mathrm{X} 3.1=$ Comply with relevant law

$\mathrm{X} 3.2=$ Not involved in common practices in the industry

Value Creation Variable (Y1)

Dimension/Indicator

Y1.1 = Customer's buying decision

Y1.2 = Customer's acquisition

Y1.3 = Development of new products and services

Y1.4 = Exploration of new markets

\section{Relational Reward Variable (Y2)}

Dimension/Indicator

Y2.1 = Customer identification

Y2.2 = Customers loyalty

Y2.3 = Customers advocacy

Marketing Performance Variable (Y3)

Dimension/Indicator

Y3.1 = Market share

\begin{tabular}{|c|c|c|}
\hline Standardized & P-value & Meaning \\
\hline $\mathbf{1 . 3 9 0}$ & 0.002 & Significant \\
\hline 0.352 & 0.000 & Significant \\
\hline $\mathbf{0 . 4 9 9}$ & 0.001 & Significant \\
\hline 0.542 & 0.001 & Significant \\
\hline 1.000 & 0.000 & Significant \\
\hline 0.767 & 0.000 & Significant \\
\hline $\mathbf{0 . 7 4 5}$ & 0.001 & Significant \\
\hline 0.601 & 0.000 & Significant \\
\hline
\end{tabular}

\begin{tabular}{|l|c|c|c|} 
& Standardized & P-value & Meaning \\
\hline & 0.575 & fixed & Significant \\
\hline and services & $\mathbf{0 . 8 0 0}$ & 0.001 & Significant \\
\hline & 0.591 & 0.001 & Significant \\
\hline & 0.451 & 0.001 & Significant \\
\hline
\end{tabular}




\begin{tabular}{|l|l|l|l|}
\hline Y3.2 $=$ Sales growth rate & $\mathbf{0 . 8 3 5}$ & fixed & Significant \\
\hline Y3.3 $=$ Net profit & 0.668 & 0.001 & Significant \\
\hline
\end{tabular}

Source: Data analysis, 2012

\subsection{Result of Hipothesis Testing}

Table 5 and 6 show the result of the hypothesis testing on the existence of direct and indirect impact of CSR strategy.

Table 5. SEM Result of Structural Model: Direct Impact

\begin{tabular}{|c|c|c|c|}
\hline Relationship between Variables & Coefisien & P-value & Meaning \\
\hline CSR Strategy $(\mathrm{X}) \rightarrow$ Value Creation (Y1) & 0.467 & $0.006^{*}$ & Significant \\
\hline CSR Strategy $(\mathrm{X}) \rightarrow$ Relational Reward (Y2) & 0.518 & $0.003^{*}$ & Significant \\
\hline CSR Strategy (X) $\rightarrow$ Marketing Performance (Y3) & 0.011 & $0.942^{\mathrm{ns}}$ & Not significant \\
\hline Value Creation (Y1) $\rightarrow$ Marketing Performance (Y3) & 0.532 & $0.003^{*}$ & Significant \\
\hline Relational Reward (Y2) $\rightarrow$ Marketing Performance (Y3) & 0.343 & $0.028^{*}$ & Significant \\
\hline
\end{tabular}

Source: Primary data analysis, 2012

Legend : $\quad$ Marker * states significancy with margin of error 5\%

Marker ns states a non-significant relationship

Table 6. SEM Result of Structural Model: Direct Impact

\begin{tabular}{|l|c|c|c|c|}
\hline $\begin{array}{l}\text { Indirect } \\
\text { Impact }\end{array}$ & $\begin{array}{c}\text { Direct Impact } \\
\text { Coeficient }\end{array}$ & $\begin{array}{c}\text { Direct Impact } \\
\text { Coeficient }\end{array}$ & $\begin{array}{c}\text { Indirect Impact } \\
\text { Coeficient }\end{array}$ & Meaning \\
\hline $\mathrm{X} \rightarrow \mathrm{Y} 1 \rightarrow \mathrm{Y} 3$ & $\mathrm{X} \rightarrow \mathrm{Y} 1=0.467$ & $\mathrm{Y} 1 \rightarrow \mathrm{Y} 3=0.532$ & $0.284^{*}$ & Significant \\
\hline $\mathrm{X} \rightarrow \mathrm{Y} 2 \rightarrow \mathrm{Y} 3$ & $\mathrm{X} \rightarrow \mathrm{Y} 2=0.518$ & $\mathrm{Y} 2 \rightarrow \mathrm{Y} 3=0.343$ & $0.178^{*}$ & Significant \\
\hline
\end{tabular}

Source: Primary data analysis, 2012

Legend: Marker * states significancy with margin or error 5\%

\subsection{Discussion}

5.6.1. The Company's Value Creation Increases in Line with the Increase of CSR Strategy

From the results of the analyses, the coefficient correlation of CSR strategy and Value Creation is 0.467 with p-value of 0.006 . Since the p-value is $<0.05$, it indicates that CSR Strategy has a significant correlation with Value Creation. In addition, the positive mark on the coefficient indicated a one-way direction. Thus, it means that the higher the value of CSR strategy, the higher the Value Creation will be.

Based on the SEM analyses, CSR strategy is measured through three aspects, namely feasibility, financial benefits, and voluntary principles, in which the first is the most crucial aspect in the measurement of CSR strategy within the present study. In other words, the worth of CSR strategy mostly lies in the feasibility aspect of CSR programs.

Value Creation is measured through four aspects in SEM, namely consumer purchase decisions, customer acquisition, product and service development, and market openness, in which the second becomes the most crucial aspect in the measurement of Value Creation. Thus, the worth of Value Creation is defined mostly by customer acquisition - in which the higher the number of new customers, the higher the Value Creation will be.

The results of the analyses indicate that the better implementation of CSR strategy has brought such a positive effect on Value Creation. This means that improvement upon CSR strategy, which can mainly be seen through improvement on its feasibility aspect, will create such higher Value Creation, which can mainly be seen through the level of customer acquisition.

\subsubsection{The Company's Relational Reward Increases in Line with the Increase of CSR Strategy}

From the results of the analyses, the coefficient correlation of CSR strategy and Relational Reward is 0.518 with $\mathrm{p}$-value of 0.003 . Since the p-value is $<0.05$, it indicates that CSR Strategy has a significant correlation with Relational Reward. In addition, the positive mark on the coefficient indicated a one-way direction. Thus, it means that the higher the value of CSR strategy, the higher the Relational Reward will be.

Based on the SEM analyses, CSR strategy is measured through three aspects, namely feasibility, financial benefits, and voluntary principles, in which the first is the most crucial aspect in the measurement of CSR strategy within the present study. In other words, the worth of CSR strategy mostly lies in the feasibility aspect of CSR programs.

Relational Reward is measured through three aspects in SEM, namely customer identification, customer loyalty, and customer advocacy, in which the first becomes the most crucial aspect in the measurement 
of Relational Reward. Thus, the worth of Relational Reward is defined mostly by customer identificationmeaning that the worth of Relational Reward can be seen through customer identification to enterprises.

The results of the analyses indicate that the better implementation of CSR strategy has brought such a positive effect on Relational Reward. This means that improvement upon CSR strategy, which can mainly be seen on its feasibility aspect, will create such higher Relational Reward, which can mainly be seen through the level of customer identification.

\subsubsection{Strong CSR Strategy Helps to Strengthen and Improve the Company's Marketing Performance}

From the analyses, the correlation coefficient of CSR Strategy and Marketing Performance is 0.011 with $p$-value 0.942 . Since the value of $p>0.05$, this indicates that CSR Strategy does not significantly affect Marketing Performance. Therefore, no matter what is the value of CSR Strategy, it will never directly affect Marketing Performance. However, the results of indirect-effect analysis on CSR Strategy (X) toward Marketing Performance (Y3) through Value Creation (Y1) produce an indirect coefficient correlation of 0.284. Due to the significant direct effect (CSR Strategy to Value Creation, and Value Creation to Marketing Performance), a conclusion may be drawn that there exists indirect significant effect between CSR Strategy toward Marketing Performance through Value Creation. It means that the better the CSR Strategy, the better the Marketing Performance will be, only if the Value Creation is also high.

This also happens to the results of indirect correlation of CSR Strategy (X) toward Marketing Performance (Y3) through Relational Reward (Y2). The correlation coefficient is 0.178 . Due to the significant direct effect (CSR Strategy to Relational Reward, and Relational Reward to Marketing Performance), a conclusion may be drawn that there exists indirect significant effect between CSR Strategy toward Marketing Performance through Relational Reward. It means that the better the CSR Strategy, the better the Marketing Performance will be, only if the Relational Reward is also high.

The results of SEM analyses are as follows:

1. CSR strategy is measured through three dimensions, namely visibility, appropriability, and voluntarism, in which the first is the most crucial aspect in the measurement of CSR strategy within the present study. In other words, the worth of CSR strategy mostly lies in the visibility dimension of CSR programs.

2. Value Creation is measured through four aspects in SEM, namely consumer's buying decisions, customer acquisition, development of new product and services, and exploration new market, in which the second becomes the most crucial aspect in the measurement of Value Creation. Thus, the worth of Value Creation is defined mostly by customer acquisition — in which the higher the number of new customers, the higher the Value Creation will be.

3. Relational Reward is measured through three aspects in SEM, namely customer identification, customer loyalty, and customer advocacy, in which the first becomes the most crucial aspect in the measurement of Relational Reward. Thus, the worth of Relational Reward is defined mostly by customer identificationmeaning that the worth of Relational Reward can be seen through customer identification to enterprises.

4. Marketing Performance is measured through three aspects, namely market share, sales growth, and profitin which the second becomes the most important aspect to measure Marketing Performance. This means that the value of Marketing Performance should mostly be seen through sales growth aspect.

From the analyses, it has been noted that better implementation of CSR Strategy will indirectly increase Marketing Performance in which Creation Value acts as the mediating factor. This means that improvement over CSR Strategy, which can mainly be seen through the feasibility aspect of CSR, will also improve Creation Value, which can mainly be seen through customer acquisition, and as such will indirectly increase Marketing Performance, which can mainly be seen through sales growth.

The results of the analyses also show that the better implementation of CSR Strategy will indirectly increase Marketing Performance in which Relational Reward acts as the mediating factor. This means that improvement over CSR Strategy, which can mainly be seen through the feasibility aspect of CSR, will also improve Relational Reward, which can mainly be seen through customer identification, and as such will indirectly increase Marketing Performance, which can mainly be seen through sales growth.

The difference of the results of the present study and previous studies lies on the mediating or intervening factors - which are Creation Value and Relational Reward. In other words, the existence of these two factors makes it possible to examine the effect of CSR Strategy toward Marketing Performance through one of those mediating factors. This means that CSR can only bring some effects on Marketing Performance when there is Creation Value and/or Relational Reward - since the direct effect of CSR Strategy toward Marketing Performance in this present study is rejected. CSR Strategy only indirectly affects Marketing Performance through the mediating factors of Creation Value and/or Relational Reward. 


\subsubsection{The Company's Marketing Performance Increases in Line with the Increase of the Company's} Value Creation

From the results of the analyses, the coefficient correlation of Value Creation and Marketing Performance is 0.532 with p-value of 0.003 . Since the p-value is $<0.05$, it indicates that Value Creation has a significant correlation with Marketing Performance. In addition, the positive mark on the coefficient indicated a one-way direction. Thus, it means that the higher the value of Value Creation, the higher the Marketing Performance will be.

Based on the SEM analyses, Value Creation is measured through four aspects, namely consumer purchase decisions, customer acquisition, product and service development, and market openness, in which the second becomes the most crucial aspect in the measurement of Value Creation. Thus, the worth of Value Creation is defined mostly by customer acquisition - in which the higher the number of new customers, the higher the Value Creation will be.

Marketing Performance is measured through three aspects in SEM, namely market share, sales growth, and profit - in which the second becomes the most important aspect to measure Marketing Performance. This means that the value of Marketing Performance should mostly be seen through sales growth aspect.

The results of the analyses show that Value Creation and Marketing Performance are positively correlated; which means that improvement over Value Creation, which can mainly be seen through customer acquisition, will also improve Marketing Performance, which can mainly be seen through sales growth.

\subsubsection{The Company's Marketing Performance Increases in Line with the Increase of the Company's Relational Reward}

From the results of the analyses, the coefficient correlation of Relational Reward and Marketing Performance is 0.343 with p-value of 0.028 . Since the p-value is $<0.05$, it indicates that Relational Reward has a significant correlation with Marketing Performance. In addition, the positive mark on the coefficient indicates a one-way direction. Thus, it means that the higher the value of Relational Reward, the higher the Marketing Performance will be.

Based on the SEM analyses, Relational Reward is measured through three aspects in SEM, namely customer's identification, customer loyalty, and customer advocacy, in which the first becomes the most crucial aspect in the measurement of Relational Reward. Thus, the worth of Relational Reward is defined mostly by customer identification - meaning that the worth of Relational Reward can be seen through customer's identification to enterprises.

Marketing Performance is measured through three aspects in SEM, namely market share, sales growth, and profit - in which the second becomes the most important aspect to measure Marketing Performance. This means that the value of Marketing Performance should mostly be seen through sales growth aspect.

The results of the analyses show that Relational Reward and Marketing Performance are positively correlated; which means that improvement over Relational Reward, which can mainly be seen through customer identification, will also improve Marketing Performance, which can mainly be seen through sales growth.

\subsection{Research Implications}

\subsubsection{Theoretical Implications}

Based on the findings, the present study is expected to have some theoretical implications as follows:

1. Concept and model developed in this study is considered a novelty, especially dealing with CSR strategy as a variable measured with Marketing Performance variable - as this has never been done by any other studies. The study has been able to examine two mediating variables on the improvement of Marketing Performance; this was done by developing and integrating two previous reseach models, by Husted \& Allen (2007) which has been able to identify the positive effect of CSR strategy toward Value Creation of companies, and by Du, Bhattacharya, \& Sen (2007) which has found that the positive feeling customers have toward CSR helps to bring Relational Reward. This has brought the idea that CSR may have some positive effects on Marketing Performance.

2. The finding on mediating roles held by Value Creation and Relational Reward on CSR Strategy toward Marketing Performance has helped to strengthen the conception on the necessity of putting mediating variables in the implementation of CSR in order to increase performance, since CSR itself does not directly and significantly affect performance. This has brought the idea over developing further theories on CSR and performance especially by exploring mediating variables in this present study and the pervious studies.

\subsubsection{Practical Implications}

Other than the theoretical implications, this present study is also expected to shed out practical implications for entrepreneurs in developing their business, especially dealing with CSR activities, such as follows: 
1. As this present study has proven that CSR Strategy brings positive effects on Marketing Performance, it is expected that business practitioners are convinced that CSR implementation is worth implemented and will bring benefits to the companies. CSR will not only bring social advantages for the society and the environment, but will also help to improve Marketing Performance. Therefore, business practitioners are expected to care more and implement CSR as a part of their business strategies.

2. For the internal management of Jawa Pos, these findings are expected to help them to evaluate their success on CSR implementation. In the future, CSR implementation should also be supported by optimal Value Creation and Relational Reward goals, as to the fact that these two variables are mediating variables to achieve company success.

\section{Conclusion}

The conclusions of the present study are as follows:

1. One of the key successes for Jawa Pos is the implementation of CSR programs.

2. CSR programs positively affect marketing performance if they are implemented as one of the business strategies.

3. CSR strategy does not directly affect marketing performance, but indirectly affects marketing performance through mediating factors of value creation and relational reward. Therefore, for CSR strategy to be effective, it should be supported by some efforts to maintain value creation and relational reward-since these two factors play such an important role in the implementation of CSR strategy in order to improve marketing performance.

4. The implementation of CSR as a social mission turns out to bring commercial benefits. Thus, synergical effects between social and commercial missions can be achieved when CSR is implemented in a proper way as one of the business strategies. CSR can be considered as a social activity which supports the main business of the company.

\section{Research Limitation}

The data of Jawa Pos agents are considered company top-secret data; this has made those external distributing agents becoming research respondents as a closed-group of people, which means that the researchers are not given any rights to know and document the identity of the agents. The researchers had such limited access to the respondents. This situation caused the researchers to only have a chance to distribute and collect the questionnaires without having any chances to dig more or to confirm the information given by the research respondents in the questionnaires.

\section{Suggestions}

Based on the discussion and conclusions of the present study, the following suggestions are presented:

1. Managers are suggested to implement CSR and integrate CSR as a strategic plan of their company as to improve marketing performance.

2. Considering the fact that there are quite few studies exploring CSR as a part of company strategy, future researchers need to examine the effect of CSR strategy toward marketing performance in the field of industry with its wide variety of enterprises. Regarding the limitation of the present studies, further studies need to have such an open-group of respondents so that studies can be conducted both in qualitative and quantitative manner in order to provide more comprehensive results. Further studies also need to focus not only on profit-oriented organizations, as this study does, but also on non-profit-oriented organizations, as to gather empirical proofs that CSR also has such good effects on performance on the latter kind of organization. Thus, CSR coverage and discussion will expand to many sectors.

3. Remembering the fact that CSR implementation in Jawa Pos is always related to news that will be published in the newspaper, the strength of CSR implementation, innovation, and development lies on the ability to create new events and/or maintaining the existing events as to keep them interesting to be written on the newspaper column. Therefore, it is obvious that creating new events and/or maintaining the existing events as to keep them interesting has become one of the keys of success for Jawa Pos in implementing CSR.

\section{References}

[1] Husted W Bryan and Allen B. David. 2007. Strategic Corporate Social Responsibilty and Value Creation among Large Firms Lessons from the Spanish Experience, Long Rang Planning, 40, 594-610

[2] Du Shuili, Bhattacharya C. B., Sen Sankar, 2007, Reaping Relational Rewards From Corporate Socisal Responsibility: The Role of Competitive Positioning, International Journal Of Research in Marketing, 24, 224-241.

[3] Falck Oliver and Heblich Stephan. 2007. Corporate Social Responsibility: Doing Well by Doing Good, Business Horizons, 50, 247254.

[4] Henderson C. Joan. 2007. Corporate Social Responsibility and Tourism: Hotel Companies in Phuket, Thailand, after The Indian Ocean Tsunami, International Journal of Hospitality Management, 26, 228-239. 
[5] Malovics Gyorgy, Nagypal Noemi, Sascha Kraus. 2007. The Role of Corporate Social Responsibility in Strong Sustainability, The Journal of Socio Economics, xxx, xxx-xxx.

[6] Levis Julien. 2006. Adoption of Corporate Social Responsibility Codes by Mulitinational Companies, Journal of Asian Economic, $17,50-55$.

[7] Olsen-Becker L. Karen, Cudmore Andrew B., Hill Paul Ronald. 2005. The Impact of Perceived Corporate Social Responsibility on Customer Behavior, Journal of Business Research, 59, 46-53

[8] Lako, Andreas. 2008. Kewajiban CSR dan Reformasi Paradigma Bisnis dan Akuntansi, Usahawan Manajemen Indonesia, No. 06 Th XXXVII, Jakarta.

[9] Indarti Sri. 2010. Pengaruh Tanggungjawab Sosial (Corporate Social Responsibility) dan Budaya Organissi Terhadap Kepuasan Kerja dan Kinerja Bisnis: Studi Pada BUMN dan BUMD di Provinsi Riau, Disertasi Program Doktor Ilmu Ekonomi, Kekhususan Manajemen PPS Univ. Brawijaya, Malang

[10] Kottler, Philip. 2003. Marketing Management, Pearson Education Inc, Upper Saddle River, New Jersey, USA.

[11] Douglas J. Evan. 1995. Managerial Economics Analysis and Strategy, Fourth Edtion, Prentice Hall Inc, Simon \& Schuster (Asian) Pte Ltd

[12] Keats, Barbara W. and Hitt, Michel A. 1988. A Causal Model of Linkages Among Environmental Dimension, MacroOrganizational Characteristics, and Performance, Academy of Management Journal, Vol. 12, pp. 35-42.

[13] Ferdinand, 2002. Structural Equetion Modeling dalam Penelitian Manajemen; Aplikasi Model-Model Rumit Dalam Penelitian Untuk Tesis Magister dan Disertasi Doctor, Edisi 2 semarang: BP Undip.

[14] Kotabe, Masaki, Dale F. Dulham K. Smith Jr,dan R. Dale Wilson, 1991, The Percieved Veracity of PIMS Strategy in Japan: An Empirical Inquiry, Journal of Marketing Theory and Practice, Vol 5, Summer, pp. 55-76.

[15] Menon, Anil, Bharadwaj G. Sundar, Adidam Tej. Phani, Edison W. Steven. 1999. Antecedents and Consequences of Marketing Strategy Making: a Model and a Test, Journal of Marketing, Vol. 63 No. 11/12, pp. 569-578.

[16] Hair, Jr., J.F., R.E Anderson, R.L. Tatham and W.C. Black. 2006. Multivariate Data Analysis with Reading. Macmillan Pub. Company. New York.

[17] PT DBL Indonesia.2010. DBL The Magazine 2009-2010, Jejaring Pena PT Jepe Press Media Utama, Surabaya.

[18] 2011, Jawa Pos No. 1 In Indoensia Word Young Reader Newspaper of the Year 2011, Jawa Pos, Surabaya 